\title{
PENGARUH KEPUASAN KERJA TERHADAP HUBUNGAN ANTARA IKLIM ORGANISASI DENGAN KINERJA PERAWAT PADA RSUD KOTA MATARAM
}

\author{
Devy Eka Hartini 1) \\ Surati ${ }^{2}$ ) \\ Hermanto $^{2}$ )
}

\begin{abstract}
This research is aimed at determining the effect of work satisfaction on the relation betweenorganizational atmosphere and performance of nurseat Mataram District Hospital. This research is an associative study. The datawerw collected through questionnaires, interview, and hospital as the population from which 162 nurses selected as the samples (besides 15 nurses were evaluated by the head of nurses). The were anlayzed using moderated regression analysis to test hipotesis. The research showed that there is significant and positive effect of organizational atmosphere and performance of nurses at Mataram District Hospitaal. The organizational atmosphere is good to boost the performance of the nurses. work satisfaction is not moderated variables but independent variable that affect the performance of the nurses of Mataram District Hospital. This means that work satisfaction directly affect the performance. The work satisfaction can make the relation between the work satisfaction and the performanceof the nurses but not significant enough. This mean that work satisfication does not affect significantly to strengthen the relation between the work satisfaction and the performance of the nurses, the relation of wihich is only $16,9 \%$, while the rest is the effect of other vaariables outside the this research problems
\end{abstract}

Keywords: work satisfaction, organizational atmosphere, performance

\subsection{Latar Belakang}

\section{PENDAHULUAN}

Rumah sakit yang merupakan lembaga pemberi pelayanan kepada masyarakat dituntut untuk memberikan pelayanan kesehatan yang profesional dan memberikan kepu ${ }^{\circledR} 1$ asan kepada pelanggan. Untuk menghadapi hal tersebut Rumah sakit harus menyiapkan tenaga profesional dan melakukan penataan sedemikian rupa agar tenagatenaga profesional tersebut dapat dimaksimalkan dalam memberikan pelayanan kesehatan (Bahtiar \& Suarli, 2002). Salah satu profesionalisme di rumah sakit yang sangat berperan dalam pelayanan kesehatan di rumah sakit adalah tenaga keperawatan (Bustami, 2011).

Menurut Aditama, (2010), bahwa kepuasan kerja perawat perlu mendapat perhatian serius dari pihak manajemen rumah sakit karena tenaga keperawatan mendominasi tenaga kesehatan secara menyeluruh dan sebagai penjalin kontak pertama dan terlama dengan pelanggan (pasien dan keluarga). Kepuasan kerja menurut Martoyo (2007:156) adalah suatu keadaan emosional karyawan di mana terjadi ataupun tidak terjadi titik temu antara nilai balas jasa kerja karyawan dari perusahaan/organisasi dengan tingkat

\footnotetext{
${ }^{1}$ Mahasiswa Program Magister Manajemen Pascasarjana Universitas Mataram

2Dosen Pembimbing Utama Dosen Program Magister Manajemen Pascasarjana Universitas Mataram

${ }^{3}$ Dosen Pembimbing Pendamping Dosen Program Magister Manajemen Pascasarjana Universitas Mataram
} 


\section{IMM JURNAL MAGISTER MANAJEMEN UNIVERSITAS MATARAM

nilai balas jasa yang diinginkan oleh karyawan yang bersangkutan. Kepuasan kerja adalah suatu perasaan positif mengenai pekerjaan yang dilakukan seseorang dan

merupakan hasil dari sebuah evaluasi karakteristiknya (Robbins \& Judge, 2015). Menurut Gomes (2003) pertimbangan subjektif seseorang tentang kepuasan kerja berhubungan dengan gaji/insentif, kondisi lingkungan kerja, supervisi, hubungan antar perorangan dalam bekerja (pimpinan dan teman sejawat) dan peluang-peluang dimasa yang akan datang (promosi).

Pegawai yang memiliki kepuasan kerja yang tinggi akan berakibat pada produktivitas atau kinerja yang tinggi, komitmen organisasional yang tinggi, tingkat stress kerja yang baik, dan cenderung akan memberikan respon yang baik terhadap organisasi, kesemua itu akan bermuara kepada kinerja organisasi yang baik. Begitu pentingnya kepuasan kerja pegawai dalam suatu organisasi, sehingga dapat disimpulkan dari keterangan di atas bahwa pegawai yang puas dalam pekerjaannya cenderung akan memberikan respon positifnya terhadap organisasi, begitu pula sebaliknya pegawai yang tidak puas dalam pekerjaannya akan cenderung memberikan respon yang tidak baik terhadap pekerjaannya, oleh karena itulah kepuasan kerja pegawai harus menjadi perhatian utama manajemen dalam suatu organisasi (Robbins, 2008).

Kepuasan kerja dapat dipengaruhi oleh iklim organisasi yang menyenangkan antara lain balas jasa yang adil dan layak, suasana dan lingkungan kerja yang menyenangkan, teman kerja yang menyenangkan, penempatan yang sesuai dengan keahlian, berat ringannya pekerjaan, peralatan yang menunjang, sikap pemimpin serta sifat pekerjaan yang dilakukan (Hasibuan, 2005).

Iklim organisasi merupakan konsep yang melukiskan sifat subjektif atau kualitas lingkungan organisasi yang unsur-unsurnya dapat dipersepsikan dan dialami oleh anggota organisasi ditempat mereka bekerja. Pengaruh iklim organisasi terhadap perilaku organisasi dapat bersifat positif atau negatif sebagai contoh hubungan atasan dan bawahan yang kurang harmonis, birokrasi yang kaku dapat menimbulkan sifat negatif, stres kerja tinggi, serta motivasi dan kepuasan kerja yang rendah. Iklim organisasi seperti ini akan menciptakan kinerja anggota organisasi rendah. Sebaliknya jika karyawan bekerja di ruangan yang nyaman dan bersih, hubungan atasan dan bawahan yang kondusif dan birokrasi yang longgar akan menimbulkan sikap positif, stres kerja rendah, serta motivasi dan kepuasan kerja yang tinggi. Dari sini akan tercipta kinerja karyawan yang tinggi (Wirawan, 2007). Iklim organisasi menjadi kekuatan utama yang mempengaruhi perilaku karyawan dalam pencapaian kinerja organisasi (Runtu \& Widyarini 2009).

Perasaan puas dalam bekerja dapat menimbulkan dampak positif terhadap perilaku, seperti misalnya tingkat kedisiplinan dan semangat kerja yang cenderung meningkat. Kepuasan kerja juga berhubungan dengan outcomes seperti kinerja, sehingga apabila kepuasan kerja semakin tinggi maka akan menimbulkan semangat dalam bekerja. Dengan demikian seseorang akan lebih mudah mencapai tingginya kinerja (Robbins, 2008).

Angkatan kerja yang puas akan memiliki kinerja yang tinggi. Kepuasan kerja yang tinggi, maka motivasi kerja juga akan meningkat yang akhirnya akan meningkatkan 


\section{IMM JURNAL MAGISTER MANAJEMEN UNIVERSITAS MATARAM

kinerja (Maharani \& Triyoga 2012). Menurut Colquitt (2009) kinerja adalah sebagai perilaku kerja pegawai yang disumbangkan untuk mencapai tujuan organisasi. Dari

pernyataan tersebut dapat dinyatakan bahwa kinerja dinyatakan sukses jika tujuan organisasi dapat tercapai dengan baik. Robbins (2000) menyatakan bahwa kinerja merupakan tolok ukur keberhasilan dalam melakukan suatu pekerjaan.Seseorang perlu bekerja untuk memenuhi kebutuhan yang diinginkan.

Rumah Sakit Umum Daerah Kota Mataram merupakan salah satu Rumah sakit pemerintah yang berada di Kota Mataram, merupakan rumah sakit rujukan, menjadi salah satu rumah sakit pilihan masyarakat Kota Mataram dengan berlakunya program BPJS. Operasional RSUD Kota Mataram Dimulai sejak Maret 2010 berdasarkan Surat Keputusan Operasional Nomor : 163/II/2010 tentang Izin penyelenggaraan Operasional Pelayanan.Rumah Sakit Umum Daerah Kota Mataram adalah tipe "B" pada Tahun 2013. Tahun 2016 RSUD Kota Mataram memiliki karyawan dengan jumlah 837 orang, terdiri dari PNS 205 orang, non PNS 632 orang.

Berdasarkan wawancara pendahuluan yang telah dilakukan oleh penulis terhadap beberapa 10 orang perawat RSUD Kota Mataram diketahui bahwa pelayanan di rumah sakit ini kadang menurun karena kurangnya koordinasi, kurang lengkapnya peralatan dan kondisi ruangan kerja yang kurang nyaman dan dari segi pengembangan karir untuk pelatihan masih kurang.

Data kepegawaian RSUD Kota Mataram terkait penilaian kinerja yang dilakukan pada 50 orang perawat diperoleh pada tahun 2014 sebagian besar kinerja perawat dalam kategori cukup 29 orang (58\%), dan kinerja perawat dalam kategori kurang sebanyak 10 orang $(20 \%)$, bahkan terdapat 2 orang perawat $(4 \%)$ tidak memenuhi standar kinerja sehingga dilakukan pemutusan hubungan kerja oleh kepegawaian RSUD.

Dari studi pendahuluan yang dilakukan di RSUD Kota Mataram didapatkan informasi bahwa sebanyak $68,7 \%$ perawat memiliki persepsi cukup terhadap iklim organisasi Rumah Sakit. 25\% perawat masih berada pada kategori tidak puas.

Berdasarkan informasi tersebut maka perlu dilakukan penelitian lebih lanjut mengenai pengaruh kepuasan kerja terhadap hubungan antara iklim organisasi dengan kinerja perawat pada RSUD Kota Mataram.

\subsection{Tujuan Penelitian}

Tujuan dari penelitian ini adalag : 1) Untuk mengetahui signifikansi pengaruh Iklim Organisasi terhadap Kinerja Perawat RSUD Kota Mataram; 2) Untuk mengetahui apakah Kepuasan Kerja dapat memoderasi pengaruh Iklim Organisasi terhadap Kinerja Perawat RSUD Kota Mataram

\section{TINJAUAN PUSTAKA}

\subsection{Kajian Hasil Riset Sebelumnyadan acuan selanjutnya}

Terdapat beberapa penelitian terdahulu yang terkait dan relevan dijadikan sebagai reverensi untuk memperjelas konsep-konsep yang ada kaitannya dengan penelitian ini, seperti Widyastuti (2004), melakukan penelitian dengan hasil secara parsial variabel budaya organisasi, iklim organisasi dan kepuasan kerja berpengaruh 


\section{IMM JURNAL MAGISTER MANAJEMEN UNIVERSITAS MATARAM

signifikan terhadap kinerja karyawan. Secara simultan variabel budaya organisasi, iklim organisasi dan kepuasan kerja berpengaruh signifikan terhadap kinerja karyawan.

Asi (2013), melakukan penelitian dengan hasiladalah iklim organisasi berpengaruh secara signifikan negatif terhadap burnout. Iklim organisasi mempunyai

pengaruh yang signifikan positif terhadap kinerja perawat. Burnout berpengaruh secara signifikan negatif terhadap kinerja perawat. Terdapat pengaruh tidak langsung iklim organisasi terhadap kinerja perawat melalui burnout.

Rosnaniar (2013), melakukan penelitian dengan hasil adalah Iklim organisasi berpengaruh signifikan terhadap kepuasan kerja.

Putra, Sudariani (2015), hasil penelitan menunjukan organisasi rumah sakit dengan Sebanyak 68,7\% perawat memiliki persepsi cukup terhadap iklim organisasi rumah sakit, $25 \%$ masih berada pada kategori tidak puas. Tidak ada hubungan iklim kepuasan kerja perawat. $(\mathrm{r}=0,249)$

\subsection{Kinerja}

Kinerja merupakan landasan organisasi, jika tidak ada kinerja maka seluruh bagian organisasi dan tujuan tidak akan tercapai. Kinerja dikatakan tinggi apabila suatu target kerja dapat diselesaikan pada waktu yang tepat atau tidak melampui batas waktu yang disediakan. Kinerja menjadi rendah jika diselasaikan melampui batas waktu yang disediakan atau sama sekali tidak terselesaikan (Nawawi, 2006:63). Kinerja adalah keluaran yang dihasilkan oleh fungsi-fungsi atau indikator- indikator suatu pekerjaan atau suatu profesi dalam waktu tertentu (Wirawan,2009 dalam Surani, (2015:64).

Menurut Windy dan Gunasti (2012) dalam Putra, P, B., 2015: 3, kinerja merupakan istilah yang berasal darikata Job Performance atau Actual Performance (prestasi kerja atau prestasi sesungguhnya dicapai seseorang). Kinerja (prestasi kerja) adalah hasil kerja secara kualitas dan kuantitas yang dicapai seorang pegawai dalam melaksanakan tugasnya sesuai dengan tanggungjawab yang diberikan kepadanya. Kinerja merujuk pada tingkat keberhasilan dalam melaksanakan tugas serta kemampuan untuk mencapai tujuan yang telah ditetapkan. Jika tujuan yang diinginkan dapat tercapai dengan baik, maka kinerja dinyatakan baik dan sukses. Anwar Prabu Mangkunegara (2009:67) menyatakan bahwa: "Faktor yang mempengaruhi pencapaian kinerja adalah faktor kemampuan (ability) dan faktor motivasi (motivation)".

1. Faktor Kemampuan

Secara psikologis, kemampuan (Ability) pegawai terdiri dari kemampuan potensi (IQ) dan kemampuan reality (knowledge + Skill). Artinya, pegawai yang memiliki IQ rata-rata (IQ 110 - 120) dengan pendidikan yang memadai untuk jabatannya dan terampil dalam mengerjakan pekerjaannya sehari-hari, maka ia akan lebih mudah mencapai prestasi kerja yang diharapkan. Oleh karena itu, pegawai perlu ditempatkan pada pekerjaan yang sesuai dengan keahliannya (the right man on the right place, the right man on the right job).

\section{Faktor Motivasi}

Motivasi terbentuk dari sikap seorang pegawai dalam menghadapi situasi kerja. Motivasi merupakan kondisi yang menggerakkan diri pegawai yang terarah untuk mencapai tujuan organisasi (tujuan kerja). 


\section{IMM JURNAL MAGISTER MANAJEMEN UNIVERSITAS MATARAM

Standar instrumen penilaian kerja perawat dalam melaksanakan asuhan keperawatan kepada klien digunakan standar praktek keperawatan yang merupakan pedoman bagi perawat dalam melaksanakan asuhan keperawatan. Prestasi kerja PNS akan dinilai berdasarkan 2 (dua) unsur penilaian, yaitu :

1. SKP (Sasaran Kerja Pegawai), yaitu: rencana kerja dan target yang akan dicapai oleh seorang PNS:

- Kuantitas ; merupakan ukuran jumlah atau banyaknya hasil kerja yang dicapai oleh seorang pegawai.

- Kualitas ; merupakan ukuran mutu setiap hasil kerja yang dicapai oleh seorang pegawai.

- Waktu ; merupakan ukuran lamanya proses setiap hasil kerja yang dicapai oleh seorang pegawai.

- Biaya ; merupakan besaran jumlah anggaran yang digunakan setiap hasil kerja oleh seorang pegawai.

2. Perilaku kerja, yaitu: setiap tingkah laku, sikap atau tindakan yang dilakukan oleh PNS tidak melakukan sesuatu yang seharusnya dilakukan sesuai dengan ketentuan atau peraturan perundang-undangan;

- Orientasi pelayanan ; merupakan sikap dan perilaku kerja PNS dalam memberikan pelayanan kepada yang dilayani antara lain meliputi masyarakat, atasan, rekan sekerja, unit kerja terkait, dan/atau instansi lain.

- Integritas ; merupakan kemampuan seorang PNS untuk bertindak sesuai dengan nilai, norma dan etika dalam organisasi.

- Komitmen ; merupakan kemauan dan kemampuan seorang PNS untuk dapat menyeimbangkan antara sikap dan tindakan untuk mewujudkan tujuan organisasi dengan mengutamakan kepentingan dinas daripada kepentingan diri sendiri, seseorang, dan/atau golongan.

- Disiplin ; merupakan kesanggupan seorang PNS untuk menaati kewajiban dan menghindari larangan yang ditentukan dalam peraturan perundangundangan atau peraturan kedinasan yang apabila tidak ditaati atau dilanggar dijatuhi sanksi.

- Kerjasama ; merupakan kemauan dan kemampuan seorang PNS untuk bekerja sama dengan rekan sekerja, atasan, bawahan baik dalam unit kerjanya maupun instansi lain dalam menyelesaikan suatu tugas dan tanggung jawab yang diembannya.

- Kepemimpinan ; merupakan kemampuan dan kemauan PNS untuk memotivasi dan mempengaruhi bawahan atau orang lain yang berkaitan dengan bidang tugasnya demi tercapainya tujuan organisasi

\subsection{Kepuasan Kerja}

Kepuasan kerja adalah suatu efektifitas atau respons emosional terhadap berbagai aspek pekerjaan, Kreitner dan Kinichi (2001:271).Sedangkan Menurut Robbins (2003:78) kepuasan kerja adalah sikap umum terhadap pekerjaan seseorang yang menunjukkan 


\section{TMM JURNAL MAGISTER MANAJEMEN UNIVERSITAS MATARAM

perbedaan antara jumlah penghargaan yang diterima pekerja dan jumlah yang mereka yakini seharusnya mereka terima.

Menurut Davis and Newstrom (2005:109) menyatakan bahwa kepuasan kerja adalah perasaan senang atau tidak senang karyawan terhadap pekerjaannya. Handoko (2011:193) kepuasan kerja merupakan keadaan emosional yang menyenangkan dengan mana para karyawan memandang pekerjaan mereka.Rivai (2003) menyatakan kepuasan kerja pada dasarnya merupakan sesuatu yang bersifat individual.Setiap individu memiliki tingkat

kepusan kerja yang berbeda-beda sesuai dengan system nilai yang berlaku pada dirinya.maka makin tinggi kepuasanya terhadap kegiatan tersebut.

Kepuasan kerja (Job satisfaction) adalah sebuah tanggapan afektif atau emosional terhadap berbagai segi pekerjaan seseorang. Definisi ini menyatakan secara tidak langsung bahwa kepuasan kerja bukanlah suatu konsep tunggal, sebaliknya seseorang dapat relatif puas dengan suatu aspek dari pekerjaannya dan tidak puas dengan salah satu atau beberapa aspek lainnya (Kreitner \& Kinicki, 2014). Robbins \& Judge (2015) mendefinisikan kepuasan kerja sebagai suatu perasaan positif tentang pekerjaan seseorang yang merupakan hasil dari sebuah evaluasi dari karakteristiknya. Seseorang dengan tingkat kepuasan tinggi memiliki perasaan yang positif terhadap pekerjaannya dan seseorang dengan level yang rendah memiliki perasaan negatif. Luthans (2006) berpendapat bahwa kepuasan kerja adalah perasaan pekerja atau karyawan yang berhubungan dengan pekerjaannya, yaitu merasa senang atau tidak senang, sebagai hasil penilaian individu yang bersangkutan terhadap pekerjaannya. Berdasarkan definisi di atas dapat disimpulkan bahwa kepuasan kerja merupakan suatu kondisi dimana seorang karyawan merasa nyaman saat berhubungan dengan pekerjaannya maupun dengan kondisi dirinya. Perasaan yang berhubungan dengan pekerjaan melibatkan aspek-aspek seperti pekerjaan itu sendiri, upah atau gaji yang diterima, kesempatan promosi atau pengembangan karir, hubungan dengan rekan kerja, penempatan kerja, pengawasan yang diterapkan.

Kreitner dan Kinicki (2005:273) mengatakan bahwa untuk mengukur kepuasan kerja dengan menggunakan indikator dalam The Minnesota Satisfaction Questionaire (MSQ) yang dikembangkan oleh Weiss, Dawis dan England pada tahun 1978 meliputi :

a. Pekerjaan itu sendiri, adapun indikator sebagai berikut:

1) Pekerjaan sangat menarik

2) Tanggung jawab dalam pekerjaan

3) Mencapai keberhasilan dalam pekerjaan

4) Kesesuaian waktu pelaksanaan

b. Rekan kerja, adapun indikator sebagai berikut:

1) Bekerja dengan memberikan dukungan yang baik

2) Melakukan pekerjaan tersebut sampai selesai

3) Menyelesaikan pekerjaan dengan teman sekerja

4) Bekerja dengan orang yang bertanggung jawab

c. kompensasi adapaun indikator sebagai berikut:

2) Gaji

3) Tunjangan kesejahteraan pegawai

4) Insentif 
d. Pengembangan karier adapaun indikator sebagai berikut:

1) Pendidikan

2) Prestasi kerja

e. Pengawasan pimpinan adapaun indikator sebagai berikut:

1) Dukungan pimpinan

2) Pimpinan memberikan motivasi kerja

3) Pimpinan mendengarkan keluhan para bawahan

4) Manajemen memperlakukan dengan jujur

\subsection{Iklim Organisasi}

Iklim organisasi adalah suasana atmosper tempat kerja yang dirasakan/ dialami oleh karyawan saat bekerja bersama dalam sebuah kelompok/organisasi (Erwita dkk, 2007).Iklim organisasi yang baik dapat mempengaruhi kepuasan kerja dan kinerja individu (Utami 2005). Iklim organisasi adalah persepsi anggota organisasi (secara individual dan kelompok) dan mereka yang secara tetap berhubungan dengan organisasi (misalnya pemasok, konsumen, konsultan dan kontraktor) mengenai apa yang ada atau terjadi di lingkungan internal organisasi secara rutin, yang mempengaruhi sikap dan perilaku organisasi dan kinerja anggota organisasi yang kemudian menentukan kinerja organisasi, (Wirawan, 2007:122).

Litwin dan Stringer, 1968 dalam Holloway B.J, (2012), berpendapat bahwa iklim organisasi adalah jumlah persepsi individu yang bekerja dalam organisasi. Iklim organisasi merupakan suatu konsep yang melukiskan sifat subjektif atau kualitas lingkungan organisasi yang mendorong motivasi sehingga berpengaruh pada kepuasan dan kinerja (Lafollete \& Sims, 1975, Biggs, Miles \& Rogers, 1980 dalam Suwanto, Priansa D.J, 2011).

Iklim organisasi merupakan konsep yang melukiskan sifat subjektif atau kualitas lingkungan organisasi yang unsur-unsurnya dapat dipersepsikan dan dialami oleh anggota organisasi ditempat mereka bekerja. Pengaruh iklim organisasi terhadap perilaku organisasi dapat bersifat positif atau negatif sebagai contoh hubungan atasan dan bawahan yang kurang harmonis, birokrasi yang kaku dapat menimbulkan sifat negatif, stres kerja tinggi, serta motivasi dan kepuasan kerja yang rendah. Iklim organisasi seperti ini akan menciptakan kinerja anggota organisasi rendah. Sebaliknya jika karyawan bekerja di ruangan yang nyaman dan bersih, hubungan atasan dan bawahan yang kondusif dan birokrasi yang longgar akan menimbulkan sikap positif, stres kerja rendah, serta motivasi dan kepuasan kerja yang tinggi.

Menurut David A. Whetten dan Kim S. Cameron (1998 dalam Fuad Mas'ud 2004) Indikator-indikator yang diukur sebagai berikut :1) Metode pengendalian manajemen, 2) Lingkungan organisasi, 3) Tujuan organisasional, 4) Penanganan konflik dalam organisasi , 5) Tingkat saling percaya antar anggota organisasi, 6) Pemanfaatan personalia, 7) Dukungan antara satu sama lain, 8) Komunikasi dalam organisasi

\subsection{Kerangka Konseptual}

\section{(a). Kerangka Konseptual}




\section{TMM JURNAL MAGISTER MANAJEMEN UNIVERSITAS MATARAM

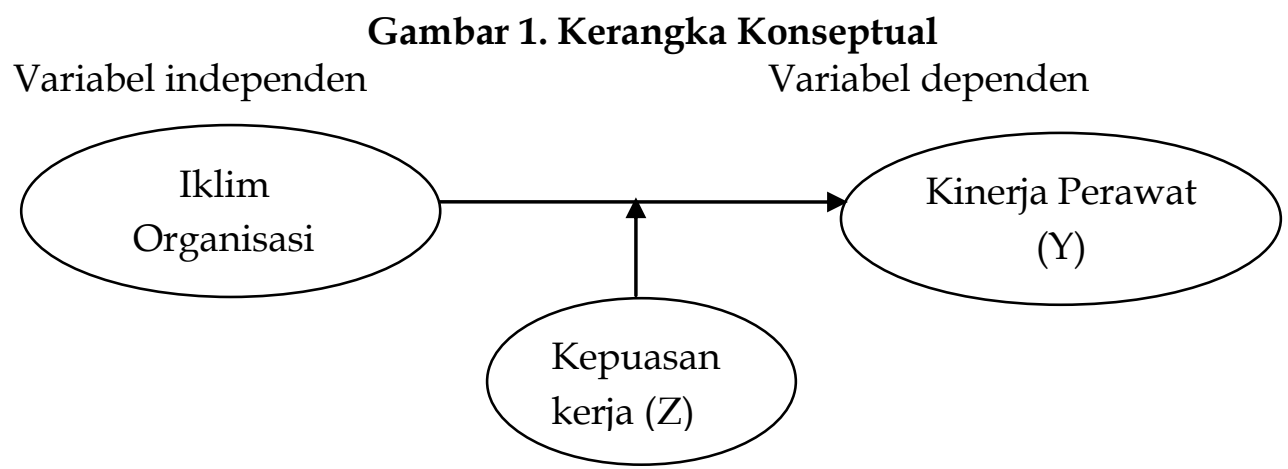

Keterangan

1) Iklim organisasi (Metode pengendalian manajemen, Lingkungan organisasi, Tujuan organisasional, Penanganan konflik dalam organisasi, Tingkat saling percaya antar anggota organisasi, Pemanfaatan personalia, Dukungan antara satu sama lain, 8) Komunikasi dalam organisasi

2) Kinerja (Sasaran kerja dan Perilaku Kerja)

3) Kepuasan Kerja (Pekerjaan itu sendiri, Rekan kerja, Kompensasi, Pengembangan Karier, Pengawasan pimpinan)

\subsection{Hipotesis}

Hipotesis dalam penelitian ini adalah: 1) Diduga Iklim organisasi berpengaruh terhadap Kinerja Perawat RSUD Kota Mataram, 2) Diduga Kepuasan Kerja berpengaruh terhadap Iklim Organisasi dengan Kinerja Perawat RSUD Kota Mataram, 3)Diduga Kepuasan Kerja dapat memperkuat hubungan iklim organisasi dengan Kinerja Perawat RSUD Kota Mataram.

\subsection{Metode Pengumpulan Data}

\section{METODE PENELITIAN}

Populasi dalam penelitian ini adalah seluruh perawat pelaksana yang tersebar diunit RSUD Kota Mataram yang berjumlah 280 orang. Teknik pengambilan sampel menggunakan metode Stratified Random Sampling dengan jumlah 162 perawat.

\subsection{Variabel dan Devinisi Operasional}

1) Variabel Iklim organisasi $(X)$

Iklim organisasi (Organizational Cimate) adalah tanggapan responden (perawat) terhadap perasaan menyenangkan dan tidak menyenangkan pada suasana dari lingkungan kerja yang dirasakan atau dilihat secara langsung dan tidak langsung oleh perawat yang bekerja dilingkungan RSUD Kota Mataram. Menurut David A. Whetten dan Kim S. Cameron (1998 dalam Fuad Mas'ud 2004) Indikator-indikator yang diukur sebagai berikut :1) Metode pengendalian manajemen, 2) Lingkungan organisasi, 3) Tujuan organisasional, 4) Penanganan konflik dalam organisasi, 5) Tingkat saling percaya antar anggota organisasi, 6) Pemanfaatan personalia, 7) Dukungan antara satu sama lain,

8)Komunikasi dalam organisasi 


\section{IMM JURNAL MAGISTER MANAJEMEN UNIVERSITAS MATARAM

2) Variabel Kinerja $(Y)$

Kinerja merupakan tanggapan responden yaitu penilaian oleh atasan langsung, pada Perawat oleh Kepala Ruangan terhadap kinerja Perawat Pelaksana yang mengacu pada Peraturan Pemerintah Nomor 46 Tahun 2011 tentang Penilaian Prestasi Kerja Pegawai Negeri Sipil dengan tujuan untuk meningkatan prestasi dan kinerja PNS. Indikator yang digunakan adalah: 1) Pengetahuan (Pemahaman dokumentasi asuhan keperawatan: Assesment awal (pengkajian) lengkap dalam 1×24 Jam, Analisis kasus (diagnosis keperawatan) sesuai prioritas, Mampu menerapkan prinsip-prinsip yang tepat dalam perencanaan dan tindakan keperawatan/ medik sesuai SAK dan SPO, 2) Keterampilan a. Penggunaan alat yang tepat dan efisien b. Pelaksanaan observasi pasien dengan benar c. Pelaksanaan tindakan keperawatan sesuai Keamanan dan Keselamatan pasien (identifikasi pasien, komunikasi efektif/SBAR, penggunaan obat yang aman: 7B dan

prosedur operasi, cuci tangan, resiko jatuh dan dekubitus, pasang infus dan injeksi obat). d. Peringkat kerja klinik: kemampuan pelaksanaan self care sesuai tingkat ketergantungan pasien e. Pelaksanaan asuhan keperawatan sesuai rencan f. Pelaksanaan pendidikan pasien dan keluarga sesuai kasus pasien, 3) Orientasi mutu pelayanan ( Menerima pasien baru dengan salam dan memperkenalkan diri (sesuai SPO), Tidak ada komplain pasien dan tim kerja, Tidak ada Kejadian Tidak Diinginkan, Melakukan penelitian askep), 4. Komitmen/ kesetiaan ( Segera melaksanakan tugas yang diberikan tanpa menundanunda, Meenunjukkna upaya optimal dalam melaksanakan tugas yang diberikan, menjaga nama baik Rumah Sakit, Memberikan pelayanan dengan menjaga nilai-nilai profesi keperawatan, 5) Integritas ( Cepat menyesuaikan diri secara baik dengan lingkungan kerja yang baru, Melaksanakan program pelayanan keperawatan di Rumah Sakit, Tanggap terhadap kebutuhan pasien, Sebagai Tim Work yang baik, 6) Kedisiplinan (Mengikuti apel pagi dan pulang (sesuai jadwal), mengikuti timbang terima shift jaga), 5) Kerjasama (Terlibat aktif dalam tim/mau membantu timyang lain, Bersedia sebagai tenaga pengganti jika ada KLB diruang lain, menjalankan delegasi tugas atasan)

\section{3) Variabel kepuasan Kerja (Z)}

Kepuasan kerja perawat RSUD merupakan tanggapan responden (perawat) terhadap perasaan puas atau tidak puas pada pekerjaannya yang ada di RSUD Kota Mataram yang diukur dengan : 1) Kepuasan terhadap pekerjaan (Tingkat kepuasan terhadap kesesuaian tugas dengan pengetahuan yang dimiliki, Tingkat kepuasan terhadap kesesuaian tugas dengan keterampilan yang dimiliki, Tingkat peluang berkreatifitas dalam menjalankan tugas, Kesesuaian dengan tugas dengan profesi), 2) Kepuasan terhadap kompensasi, Kesesuaian dengan organisasi lainnya, Kesesuaian tunjangan kinerja dengan banyaknya tugas, Keseseuaian/keadilan (insentif / jasa pelayanan) yang diterima dengan beban kerja), 3) Kepuasan terhadap teman sekerja (Tingkat kepuasan terhadap hubungan kerja dengan rekan kerja,Tingkat kepuasan terhadap rekan kerja dalam hubungan kolaborasi, Tingkat kepuasan terhadap rekan kerja yang bertanggung jawab terhadap pekerjaannya), 4) Kepuasan terhadap promosi (Tingkat kepuasan terhadap standar promosi yang dilakukan instansi,Tingkat kepuasan terhadap aspek prestasi sebagai patokan promosi,Tingkat kepuasan terhadap penghargaan yang diberikan,Tingkat kepuasan terhadap reward atasan terhadap pekerjaan), 5) Kepuasan terhadap penyelia (Tingkat kepuasan terhadap hubungan dengan atasan, Tingkat 


\section{TMM JURNAL MAGISTER MANAJEMEN UNIVERSITAS MATARAM UNRAM VOL. 6 No. 1 MARET 2017}

kepuasan terhadap pengawasan yang diberikan atasan, Tingkat kepuasan terhadap perintah yang diberikan atasan, Pemberian motivasi atas pekerjaan).

\subsection{Teknik Analisis Data}

\section{1) Analisis Asosiatif}

Analisis asosiatif dimaksudkan untuk mengetahui hubungan dua variabel atau lebih yaitu pengaruh kepuasan kerja terhadap hubungan antara iklim organisasi dengan kinerja perawat pada Rumah Sakit Umum Daerah Kota Mataram.

Untuk mengetahui dan menganalisis variabel-variabel penelitian tersebut, peneliti menggunakan analisis tabel dari data frekuensi atau nilai skor rata-rata dari masingmasing variabel. Penggalian data peneliti menggunakan tipe data berbentuk skala, yakni dengan merefrensi atau mengadopsi skala likert dengan 5 ketukan (point), yakni skore $1=$

sangat tidak setuju, skore 2 = tidak setuju, skore $3=$ cukup, skore $4=$ setuju dan skore $5=$ sangat setuju. Nilai skor dari masing-masing variabel dikomversi sesuai dengan sifat variabel. Mengingat bahwa setiap variabel atau item variabel yang digali datanya dari banyak responden, maka nilai skore rata-rata bisa bervariasi, sehingga untuk memudahkan pembahasan dan penafsiran data atau nilai skore dari setiap variabel atau sub variabel dapat dikelompokkan dan dikonversi kedalam sifat dari masing-masing variabel penelitian, sebagaimana terlihat pada Tabel 1 .

Tabel 1: Rata-Rata Total Variabel Berdasarkan Jawaban responden

\begin{tabular}{|c|c|c|c|}
\hline \multirow{2}{*}{ Interval } & \multicolumn{3}{|c|}{ Kategori } \\
\cline { 2 - 4 } & Kepuasan Kerja & Kinerja & Iklim organisasi \\
\hline$\geq 4,2$ & Sangat Puas & Sangat tinggi & Sangat menyenangkan \\
3,4 sampai dengan $<4,2$ & Puas & Tinggi & Menyenangkan \\
2,6 sampai dengan $<3,4$ & Cukup Puas & Cukup & Cukup menyenangkan \\
1,8 sampai dengan $<2,6$ & Kurang Puas & Rendah & Kurang menyenangkan \\
$\leq 1,7$ & Tidak Puas & Sangat rendah & Tidak menyenangkan \\
\hline
\end{tabular}

\section{2) Moderated Regression analysis (MRA)}

Dalam penelitian ini model dan teknik analisa data menggunakan pendekatan Regresi dengan variabel moderating (MRA). Salah satu cara yang dapat digunakan untuk menguji apakah suatu variabel merupakan variabel moderating yakni dengan melakukan uji interaksi. Regresi dengan melakukan uji interaksi antar variabel disebut dengan Moderated Regression analysis (Utama, 2009). MRA merupakan aplikasi khusus regresi berganda liniear dimana dalam persamaan regresinya mengandung unsur interaksi (perkalian dua atau lebih variabel independen) (Liana, 2009).

Model analisis regresi moderating menguji hipotesis dengan tingkat keyakinan 5\% dapat dilakukan dengan bantuan program SPSS. Model regresi dilakukan dengan uji t. Apabila tingkat signifikansi $\mathrm{t} \leq$ a 0,05 maka hipotesis diterima atau sebaliknya jika tingkat signifikansi $t>0,05$ maka hipotesis ditolak. Analisis regresi moderasi digunakan untuk mengetahui pengaruh variabel-variabel yang diteliti, utamanya apakah variabel moderasi memperkuat atau memperlemah pengaruh terhadap variabel Y (Ghozali, 2006). Moderated Regression Analysis dinyatakan dalam bentuk regresi berganda dengan persamaan mirip 


\section{TMM JURNAL MAGISTER MANAJEMEN UNIVERSITAS MATARAM

regresi polynomial yang menggambarkan pengaruh nonlinier (Hair, 2010 : 176). Moderated Regression Analysis dinyatakan dalam bentuk model persamaan sebagai berikut :

$$
\begin{aligned}
& Y=\alpha+\beta_{1} X_{1}+\beta_{2} Z_{2}+\beta_{3} X_{1} * Z_{2} \\
& \text { Keterangan : } \\
& \mathrm{Y}=\text { Kinerja } \\
& \text { a } \quad=\text { Konstanta } \\
& \beta_{1}, \beta_{2}, \beta_{3}=\text { Koefisien Regresi } \\
& X \quad=\text { Variabel Indipenden } \\
& \mathrm{X} 1{ }^{*} \mathrm{Z} 2=\text { Interaksi antara variabel intruksi }
\end{aligned}
$$

4. HASIL PENELITIAN

4.1 Karakristik Responden Berdasarkan Umur, Jenis Kelamin, Tingkat Pendidikan, dan Masa Kerja.

Jumlah responden dengan rincian menurut kelompok dapat dilihat pada tabel 2. dibawah ini :

Tabel 2. Karakteristik Responden perawat RSUD Kota Mataram.

\begin{tabular}{|c|c|c|c|}
\hline \multicolumn{2}{|c|}{ Karakteristik Responden } & Frekuensi (org) & Persentase (\%) \\
\hline \multirow{4}{*}{ Umur (Tahun) } & $21-30$ & 143 & 88 \\
\cline { 2 - 4 } & $31-40$ & 18 & 11 \\
\cline { 2 - 4 } & $>40$ & 1 & 1 \\
\hline \multirow{3}{*}{ Jenis Kelamin } & Laki-laki & 42 & 26 \\
\cline { 2 - 4 } & Perempuan & 120 & 74 \\
\hline \multirow{4}{*}{\begin{tabular}{c} 
Tingkat \\
\cline { 1 - 3 }
\end{tabular}} & SLTA & 1 & 1 \\
\cline { 2 - 4 } & D III & 44 & 27 \\
\cline { 2 - 4 } & D IV & 1 & 1 \\
\cline { 2 - 4 } & S1 kep & 52 & 42 \\
\cline { 2 - 4 } & Ners & 64 & 0 \\
\hline \multirow{3}{*}{ Masa Kerja } & S2 & 0 & 86 \\
\cline { 2 - 4 } & $<6$ & 21 & 13 \\
\cline { 2 - 4 } & $6-10$ & 2 & $\mathbf{1 0 0} \%$ \\
\hline
\end{tabular}

Sumber: Data primer diolah, 2016

Berdasarkan tabel 2. tersebut dapat dilihat bahwa responden terbanyak adalah pada kelompok umur 21-30 tahun yaitu 143 orang perawat dengan presentase $88 \%$. Sedangkan kelompok umur yang paling sedikit adalah kelompok umur $>40$ tahun sebanyak 1 orang perawat dengan presentasi 1\%. Hal ini menunjukkan bahwa umur responden atau perawat RSUD Kota Mataram banyak berusia berkisar usia 21-30 tahun, 


\section{IMM JURNAL MAGISTER MANAJEMEN UNIVERSITAS MATARAM

hal ini menunjukkan bahwa umur 21-30 merupakan usia produktif, energik dalam meniti karir, memiliki semangat dan motivasi kerja tinggi, cepat melakukan perubahanperubahan yang dapat mendorong terciptanya kualitas kerja yag baik. Nitisemito (2001) menyatakan bahwa," Pegawai yang lebih muda cenderung mempunyai fisik yang lebih kuat, sehingga dapat bekerja keras dan pada umumnya mereka belum berkeluarga atau anaknya relatif sedikit."

Responden yang berjenis kelamin perempuan, yaitu sebanyak 120 orang perawat dengan presentase $74 \%$, dan sisanya adalah responden yang berjenis kelamin laki-laki, yaitu sebanyak 42 orang perawat dengan presentase $26 \%$. Jadi pada penelitian ini lebih dominan responden perempuan dari pada laki-laki. Hal ini terjadi karena jumlah responden (karyawan di Rumah Sakit Umum Daerah Kota Mataram) yang berjenis kelamin perempuan lebih banyak dibandingkan jumlah laki-laki, dan hal ini sesuai dengan penelitian dari Prayoga (2009), yag menyatakan bahwa perempuan mempunyai sifat lemah lembut, teliti, dan lebih emosionalsehingga membuat profesi perawat dianggap lebih cocok bagi para perempuan.

Responden sebagian besar berpendidikan Sarjana (S1), yaitu S1 kep sebanyak 52 orang perawat dengan presentse 32\% dan Ners sebanyak 64 orang perawat dengan presentase $40 \%$. Sedangkan yang mempunyai tingkat pendidikan SLTA, dan D IV adalah yang terkecil, yaitu sebanyak 1 orang perawat dengan presentse $1 \%$. Jadi yang lebih dominan terlihat tingkat pendidikan sarjana (S1) dan ners. hal ini sesuai dengan penelitian Suprihanto (2000) yang menyatakan bahwa pendidikan formal dapat memberi kesempatan berprestasi yang lebih baik pada diri seorang pekerja.

Sedangkan responden dengan masa kerja 6 sampai dengan 10 tahun sebanyak 21 atau 13\%. Sedangkan masa kerja kurang dari 6 tahun sebanyak 169 orang perawat atau $86 \%$ dan lebih dari 10 tahun sebanyak 2 orang perawat. Hal ini menunjukkan bahwa masa kerja perawat yang menjadi responden pada RSUD Kota Mataram sudah dikategorikan cukup lama, selain itu opersional RSUD Kota Mataram baru di mulai Maret 2010 berdasarkan Surat Keputusan Opersional Nomor: 163/II/2010 tentang izin penyelenggaraan Opersional Pelayanan, dan memiliki karyawan 837 orang dengan komposisi terdiri dari PNS 205 orang dan non PNS 632 orang.

\subsection{Analisis MRA}

\subsubsection{Hipotesis Pertama}

Hasil pengujian regresi I dengan iklim organisasi sebagai variabel independen dan kinerja sebagai variabel dependen dapat dijelaskan pada tabel berikut:

Tabel 3. Hasil Model Regresi 1

\begin{tabular}{|l|r|r|r|r|}
\hline Model & R & R Square & $\begin{array}{c}\text { Adjusted R } \\
\text { Square }\end{array}$ & $\begin{array}{c}\text { Std. Error of } \\
\text { the Estimate }\end{array}$ \\
\hline 1 & $.238 \mathrm{a}$ & .157 & .151 & 6.42967 \\
\hline
\end{tabular}

Sumber : Data Primer Diolah Dengan SPSS Versi 16 pada Lampiran 4 


\section{TMM JURNAL MAGISTER MANAJEMEN UNIVERSITAS MATARAM

Koefisien determinasi $\left(\mathrm{R}^{2}\right)$ yaitu untuk mengukur seberapa besar kemampuan variabel bebas dalam menerangkan variabel terikat yaitu kinerja perawat. Angka adjusted $R$ square pada tabel diatas, menunjukkan koefisien determinasi atau peranan variance (variabel independen dalam hubungan dengan variabel dependen). Angka adjusted $R$ square sebesar 0,151 menunjukkan bahwa hanya 15,1\% variabel kinerja yang bisa dijelaskan oleh variabel iklim organisasi, sisanya 84,9\% (100\%-15,1\%) dijelaskan oleh faktor lain seperti motivasi kerja, lingkungan kerja.

Tabel 4. Signifikansi Nilai t Model Regresi I

\begin{tabular}{|c|c|c|c|c|c|c|}
\hline \multirow{2}{*}{\multicolumn{2}{|c|}{ Model }} & \multicolumn{2}{|c|}{$\begin{array}{l}\text { Unstandardized } \\
\text { Coefficients }\end{array}$} & \multirow{2}{*}{\begin{tabular}{|c|}
$\begin{array}{c}\text { Standardized } \\
\text { Coefficients }\end{array}$ \\
Beta
\end{tabular}} & \multirow[b]{2}{*}{$t$} & \multirow[b]{2}{*}{ Sig. } \\
\hline & & B & Std. Error & & & \\
\hline 1 & (Constant) & 106.658 & 4.248 & & 25.106 & .000 \\
\hline & $X$ & .391 & .126 & .238 & 3.097 & .002 \\
\hline
\end{tabular}

Sumber : Data Primer Diolah Dengan SPSS Versi 16 pada Lampiran 4

Hasil analisis regresi I (Tabel 4.13) menunjukkan $\mathrm{t}$ hitung iklim organisasi adalah sebesar 3.097 dengan signifikansi t bernilai 0,002 (siginifikan) dan koefisien regresi sebesar 0,391 . Hal ini berarti bahwa iklim organisasi mempunyai pengaruh positif dan signifikan terhadap kinerja perawat.

\subsubsection{Hipotesis Kedua}

Hasil pengujian regresi II akan menjelaskan bahwa Kepuasan Kerja berpengaruh terhadap hubungan Iklim Organisasi dengan Kinerja Perawat pada RSUD Kota Mataram yang disajikan pada tabel berikut.

Tabel 5. Signifikansi Nilai F Model Regresi II

\begin{tabular}{|ll|r|r|r|r|r|}
\hline \multicolumn{1}{|l|}{ Model } & \multicolumn{1}{|c|}{$\begin{array}{l}\text { Sum of } \\
\text { Squares }\end{array}$} & \multicolumn{1}{c|}{ Df } & Mean Square & F & \multicolumn{1}{c|}{ Sig. } \\
\hline 1 & Regression & 603.205 & 3 & 201.068 & 4.958 & $.003 \mathrm{a}$ \\
Residual & 6407.906 & 158 & 40.556 & & \\
Total & 7011.111 & 161 & & & \\
\hline
\end{tabular}

Sumber : Data Primer Diolah Dengan SPSS Versi 16 pada Lampiran 4

Dari Tabel 4.14 diatas, nilai Fhitung adalah sebesar 4,958 dengan tingkat signifikansi 0,003 lebih kecil daripada 0,05. Hal ini menunjukkan bahwa iklim organisasi dan kepuasan kerja berpengaruh secara bersama-sama terhadap kinerja perawat pada RSUD Kota Mataram. 


\section{TMM JURNAL MAGISTER MANAJEMEN UNIVERSITAS MATARAM

Tabel 6. Signifikansi Nilai t Model Regresi II

\begin{tabular}{|c|c|c|c|c|c|c|}
\hline \multirow{2}{*}{\multicolumn{2}{|c|}{ Model }} & \multicolumn{2}{|c|}{$\begin{array}{c}\text { Unstandardized } \\
\text { Coefficients }\end{array}$} & \multirow{2}{*}{\begin{tabular}{|c|}
$\begin{array}{c}\text { Standardized } \\
\text { Coefficients }\end{array}$ \\
Beta \\
\end{tabular}} & \multirow[b]{2}{*}{$\mathrm{t}$} & \multirow[b]{2}{*}{ Sig. } \\
\hline & & B & Std. Error & & & \\
\hline 1 & (Constant) & 91.665 & 21.087 & & 4.347 & .000 \\
\hline & $X$ & .351 & .659 & .214 & .533 & .595 \\
\hline & Z & .180 & .315 & .244 & .573 & .568 \\
\hline & $X Z$ & .009 & .010 & .669 & .985 & .326 \\
\hline
\end{tabular}

Sumber : Data Primer Diolah Dengan SPSS Versi 16 pada Lampiran 4

Hasil analisis regresi II (Tabel 4.15) menunjukkan $t$ hitung iklim organisasi adalah sebesar 0,533 dengan signifikansi t bernilai 0,595 (tidak siginifikan). Variabel kepuasan kerja mempunyai $t$ hitung sebesar 0,573 dengan signifikansi 0,568 (tidak signifikan). Variabel $X^{\star} Z$ (interaksi antara variabel iklim organisasi dan kepuasan kerja) mempunyai $t$ hitung sebesar 0,362 dengan signifikansi 0,985 (tidak signifikan). Hal ini berarti variabel

kepuasan kerja bukan merupakan pemoderasi dalam pengaruh terhadap hubungan antara iklim organisasi dengan kinerja.

Pada analisis regresi moderating mempunyai 4 jenis moderasi yaitu

1. Moderasi murni (Pure Moderator) dimana hasil uji $b_{2}$ non signifikan dan $b_{3}$ signifikan

2. moderasi semu (Quasi Moderator) yaitu merupakan variabel yang memoderasi hubungan antara variabel independen dengan variabel dependen yang sekaligus menjadi variabel independen. Dimana hasil uji jika $b_{2}$ signifikan dan $b_{3}$ signifikan.

3. moderasi potensial (homologiser moderator) artinya variabel tersebut potensi menjadi variabel moderasi. Dimana hasil uji $b_{2}$ non signifikan dan $b_{3}$ non signifikan.

4. Moderasi prediktor artinya variabel moderasi ini hanya berperan sebagai variabel prediktor (independen) dalam model hubungan yang dibentuk. Dimana hasil uji $b_{2}$ signifikan dan $b_{3}$ non signifikan.

Jadi dalam penelitian ini, jenis MRA pada hasil ini adalah moderasi semu (Quasi Moderator). Quasi moderasi merupakan variabel yang memoderasi hubungan antara variabel iklim organisasi dengan variabel kinerja yang sekaligus menjadi variabel kepuasan kerja sebagai variabel independen.

\subsection{PEMBAHASAN}

1) Pengaruh Iklim organisasi terhadap Kinerja Perawat pada RSUD Kota Mataram".

Hasil penelitian ini menunjukkan bahwa iklim organisasi berpengaruh signifikan terhadap kinerja perawat. Hasil 1 analisis data tersebut secara keseluruhan memberikan petunjuk bahwa iklim organisasi punya pengaruh positif dan signifikan terhadap kinerja Perawat pada RSUD Kota Mataram. Dengan kata lain dapat dikatakan bahwa kinerja Perawat pada RSUD Kota Mataram antara lain merupakan fungsi atau sebab dari iklim organisasi tersebut. Dengan demikian, hipotesis yang diajukan dalam penelitian ini yakni “iklim organisasi berpengaruh signifikan terhadap kinerja Perawat pada RSUD Kota Mataram, dapat dinyatakan teruji/diterima secara meyakinkan berdasarkan data empirik. 


\section{JMM JURNAL MAGISTER MANAJEMEN UNIVERSITAS MATARAM

Hasil penelitian ini sesuai dengan penelitian Widyastuti (2004), Basuki dan Asi (2013), yang membuktikan bahwa iklim organisasi berpengaruh signifikan terhadap kinerja. Dalam penelitian Widyastuti, Basuki dan Asi melihat bahwa iklim organisasi secara parsial berpengaruh langsung pada kinerja pegawai, dimana iklim organisasi adalah salah satu faktor yang mempengaruhi kinerja. Penelitian Junandi dan Maryono (2012) juga membuktikan bahwa iklim organisasi berpengaruh terhadap kinerja. Junandi dan Maryono mencoba melakukan analisis terhadap kinerja pegawai pada Pustakawan Universitas Gajah Mada dan hasilnya bahwa iklim organisasi dapat berpengaruh terhadap kinerja, dimana hasil temuan ini bahwa iklim organisasi dan kinerja memiliki hubungan dan pengaruh yang sangat kuat. Menurut Runtu \& Widyarini (2009) bahwa iklim organisasi menjadi kekuatan utama yang mempengaruhi perilaku karyawan dalam pencapaian kinerja organisasi. Iklim organisasi merupakan konsep yang melukiskan sifat subjektif atau kualitas lingkungan organisasi yang unsur-unsurnya dapat dipersepsikan dan dialami oleh anggota organisasi ditempat mereka bekerja.

Hasil penelitian ini sekaligus membuktikan teori Gibson et al. (2008) bahwa iklim organisasi diartikan sebagai seperangkat sifat-sifat lingkungan kerja yang dirasakan baik secara langsung maupun tidak langsung oleh pegawai dan diduga berpengaruh terhadap perilaku kerjanya. Iklim organisasi berhubungan dengan pola perilaku berulang yang

ditunjukkan dalam lingkungan keseharian dari organisasi, sebagai pengalaman, pemahaman, dan interpretasi individu dalam organisasi (Ekvall, 1996). Hal ini mengenai persepsi seseorang yang mempengaruhi sikap dan perilaku dalam bekerja seperti kinerja dan tingkat produktivitas. Iklim organisasi merupakan gambaran kolektif yang bersifat umum terhadap suasana kerja organisasi yang membentuk harapan dan perasaan seluruh karyawan sehingga kinerja karyawan meningkat. Iklim organisasi tersebut sangat mempengaruhi kinerja karyawan yaitu dengan menciptakan iklim organisasi yang sehat dalam perusahaan. Dengan demikian, para karyawan akan semakin bersemangat dan diharapkan dapat meningkatkan kinerja karyawan. Castetter (1981 : 281) berpendapat bahwa secara umum terdapat tiga sumber utama yang mempengaruhi efektif tidaknya kinerja sesorang yaitu faktor individu, faktor organisasi dan faktor lingkungan yang didalamnya termasuk iklim organisasi.

2) Kepuasan Kerja sebagai moderasi hubungan Iklim Organisasi terhadap Kinerja Perawat pada RSUD Kota Mataram".

Hasil penelitian ini menunjukkan bahwa secara langsung kepuasan kerja tidak berpengaruh signifikan terhadap kinerja perawat. Hasil 2 analisis data tersebut secara keseluruhan memberikan petunjuk bahwa kepuasan kerja mempunyai pengaruh positif namun tidak signifikan terhadap kinerja Perawat pada RSUD Kota Mataram. Dengan kata lain dapat dikatakan bahwa kepuasan kerja bukan merupakan variabel moderasi yang dapat membantu pengaruh secara langsung antara iklim organisasi dengan kinerja Perawat pada RSUD Kota Mataram. Dengan demikian, hipotesis ini menolak hipotesis kedua yang diajukan dalam penelitian ini yakni "Kepuasan Kerja berpengaruh secara langsung terhadap Iklim Organisasi dengan Kinerja. Dari hasil temuan penelitian ini, Widyastuti (2004) dalam hasil penelitiannya mempertegas bahwa kepuasan kerja tidak dapat berfungsi sebagai pemoderasi dalam hubungan iklim organisasi dengan kinerja, namun dalam penelitian Widyastuti justru membuktikan bahwa kepuasan kerja adalah 


\section{IMM JURNAL MAGISTER MANAJEMEN UNIVERSITAS MATARAM

merupakan variabel intervening yang secara tidak langsung dapat mempengaruhi kinerja pegawai. Hasil penelitian ini dan penelitian Widyastuti dapat diperkuat oleh penelitian Ulhaq (2013), bahwa iklim organisasi bepengaruh signifikan secara tidak langsung melalui kepuasan kerja.

Menurut Davis, (2002) Iklim organisasi merupakan suatu gambaran lingkungan dan sifat-sifat lingkungan kerja yang ada dalam suatu organisasi kerja dimana pegawai melakukan pekerjaannya secara terus menerus yang menyenangkan ataupun tidak menyenangkan. Iklim organisasi memberikan pengaruh yang besar terhadap kepuasan kerja karyawan. Sudaryani (2015), dalam kajiannya tentang hubungan iklim organisasi dengan kepuasan kerja perawat, terlihat bahwa sebanyak $68,7 \%$ perawat memiliki persepsi cukup terhadap iklim organisasi rumah sakit, sedangkan 31,3\% masih berada pada kategori tidak puas.

Dalam hasil regresi ketiga membuktikan bahwa iklim organisasi dan kepuasan kerja merupakan variabel independen yang dapat mempengaruhi kinerja Perawat pada RSUD Kota Mataram. Hasil penelitian menunjukkan bahwa iklim organisasi dan kepuasan kerja bepengaruh secara bersama-sama maupun secara individu pada kinerja Perawat pada RSUD Kota Mataram. Hasil temuan ini sesuai dengan penelitian yang dilakukan oleh Wahyuni (2010), membuktikan bahwa iklim organisasi dan kepuasan kerja berpengaruh positif dan signifikan secara bersamaan dan individu pada kinerja

pegawai. Dengan demikian Wahyuni berasumsi bahwa makin baik iklim organisasional maka makin baik pula kinerja pegawai. Serta makin baik kepuasan kerja maka makin baik pula kinerja pegawai. Hasil temuan penelitian ini dan penelitian Wahyuni, dipertegas oleh hasil penelitian Panduwinata (2012) memperlihatkan bahwa terdapat pengaruh langsung positif signifikan iklim organisasi terhadap kinerja, tidak terdapat pengaruh langsung positif signifikan kepuasan terhadap kinerja, terdapat pengaruh langsung positif signifikan iklim organisasi terhadap kepuasan kerja, dan tidak terdapat pengaruh tidak langsung iklim organisasi terhadap kinerja guru melalui kepuasan kerja. Hasil penelitian ini, wahyuni, dan Panduwinata dapat dipertegas oleh penelitian yang dilakukan oleh Herman, AR, dan Ibrahim (2014), membuktikan bahwa iklim organisasi dan kepuasan kerja secara langsung berpengaruh signifikan terhadap tinggi rendahnya kinerja guru.

Perlu diketahui bahwa setiap organisasi akan memiliki iklim organisasi yang berbeda, iklim organisasi yang terbuka memacu karyawan untuk mengutarakan kepentingan dan ketidakpuasan tanpa adanya rasa takut akan tindakan balasan dan perhatian. Ketidakpuasan seperti itu dapat ditangani dengan cara yang positif dan bijaksana (Simamora, 2001:81).

Menurut Davis (2002) ada dua aspek yang penting yang harus diperhatikan dalam iklim organisasi, yaitu tempat kerja itu sendiri dan perlakuan yang diterima dari manajemen. Karyawan merasakan bahwa iklim organisasi tertentu menyenangkan bila mereka melakukan sesuatu yang berguna yang memberikan kemanfaatan pribadi. Dengan demikian, iklim organisasi yang diciptakan memegang peranan penting dalam kemampuan organisasi menciptakan tujuannya. Iklim organisasi adalah iklim manusia di dalam, dimana para anggota organisasi melakukan pekerjaan mereka. Iklim organisasi merupakan sebuah konsep yang menggambarkan suasana internal lingkungan organisasi 


\section{IMM JURNAL MAGISTER MANAJEMEN UNIVERSITAS MATARAM

yang dirasakan anggotanya selama mereka beraktivitas dalam rangka tercapainya tujuan organisasi (Davis dan Newstorm, 2002). Iklim organisasi sebagai salah satu sistem sosial dipengaruhi oleh lingkungan internal dan eksternal. Lingkungan internal meliputi: desain pekerjaan dan aplikasi teknologi, kultur organisasi dan praktek-praktek manajerial, serta karakteristik anggota. Sedangkan lingkungan eksternal meliputi lingkungan sosial dan ekonomi dimana organisasi berada. Paduan lingkungan eksternal dan internal tersebut akan mempengaruhi kepuasan kerja, produktivitas dan pertumbuhan organisasi.

Menurut Wirawan (2008:122) iklim organisasi adalah persepsi anggota organisasi (secara individual atau kelompok) dan mereka yang secara tetap berhubungan dengan organisasi mengenai apa yang ada atau terjadi dilingkungan internal organisasi secara rutin, yang mempengaruhi sikap dan perilaku organisasi dan kinerja anggota organisasi yang kemudian menentukan kinerja organisasi.

Menurut Gibson (2008) ada 3 faktor yang berpengaruh terhadap kinerja : 1) Faktor individu : kemampuan, ketrampilan, latar belakang keluarga, pengalaman kerja, tingkat sosial dan demografi seseorang. 2) Faktor psikologis : persepsi, peran, sikap, kepribadian, motivasi dan kepuasan kerja 3) Faktor organisasi : struktur organisasi, desain pekerjaan, kepemimpinan, sistem penghargaan (reward system).

Jadi dapat disimpulkan dari kajian pustaka dan pendapat para ahli, bahwa kepuasan kerja merupakan variabel independen bukan variabel moderasi antara iklim

organisasi dan kinerja. Oleh karena itu, iklim organisasi dan kepuasan kerja merupakan variabel independen yang dapat mempengaruhi kinerja pegawai.

\section{KESIMPULAN}

Kesimpulan dari penelitin ini adalah:

a). Terdapat pengaruh yang positif signifikan Iklim Organisasi terhadap Kinerja Perawat RSUD Kota Mataram. Iklim organisasi di lingkungan kerja perawat sudah puas dan dirasakan dapat meningkatkan kinerja perawat.

b). Kepuasan kerja bukan variabel moderasi dan kepuasan kerja adalah sebagai variabel independen yang berpengaruh terhadap kinerja perawat RSUD Kota Mataram. Hasil ini menunjukkan bahwa kepuasan secara langsung berpengaruh terhadap kinerja.

\section{DAFTAR PUSTAKA}

Aditama, T. Y., 2010, Manajemen Administrasi Rumah Sakit, 143, UI Press, Jakarta.

Aydogdu, S \& Asikgil,B., 2011. An empirical study of the relationship among job satisfaction, Organizational commitment and turnover intention, international review of management and marketing. Vol. 1(3), pp. 43 - 53.

Arikunto, Suharsimi, 2006. Prosedur Penelitian: Suatu Pendekatan Praktik. Edisi Revisi VI. Penerbit PT. Rineka Cipta. Jakarta.

Asi, F (2013), Pengaruh Iklim Organisasi dan Burnout terhadap Kinerja Perawat RSUD dr. Doris Sylvanus Palangka Raya. Jurnal Aplikasi Manajemen.II (3). 


\section{IMM JURNAL MAGISTER MANAJEMEN UNIVERSITAS MATARAM

Bahtiar \& Suarli.(2002).Manajemen keperawatan. Jakarta: PT Gelora Aksara Pratama.

Basuki, (2013). Pengaruh Budaya dan Iklim Organisasi Terhadap Kepuasan Kerja Serta Dampaknya pada Kinerja Karyawan Divisi Produksi PT SMU Jakarta. UNTAG Jakarta.

Bustami, 2011. Penjaminan Mutu Pelayanan Kesehatan \& Akseptabilitasnya. Jakarta: Erlangga.

Bidang Kepegawaian (2014). “Laporan Hasil Kegiatan Kinerja Pegawai RSUD Kota Mataram 2014.

Colquitt Jasson A., Jefferi A. Lepine, Michael J. Wesson, 2009. Organizational Behavior. New York: Mc Graw Hil

Castetter, William B., 1981. The Personnel Function in Educational Administration New York : Mc Millan Publishing.

Davis, Keith dan Newstrom, W. John. 2002. Organization Behavior: Human Behavior At Work. 11th Edition, Mc.Graw-Hill, Inc,.Singapore.

Dessler, G., (2011), Manajemen sumber daya manusia, Jakarta : Penerbit Indeks,

Erwita, Handono D., Trisnantoro L., 2007, "Pengaruh Workgroup Climate Assessment (WCA) Mini Workshop Terhadap Iklim Kerja Dan Kinerja Puskesmas Di Kota Jambi", Jurnal: KMPK, Program Magister Kebijakan dan Manajemen Pelayanan Kesehatan, Universitas Gadjah MadaYogyakarta.

Ekvall G. 1996. Organizational Climate for Creativity and Innovation. European Journal of Work and Organizational Psychology, 5:pp105-123.

Mas'ud, Fuad, 2004, Survai Diagnosis Organisasional Konsep dan Aplikasi, BP UNDIP

Ghozali, Imam, 2006. Aplikai Analisis Multivarite dengan SPSS, Cetakan Keempat, Badan Penerbit Universitas Diponegoro, Semarang.

Gomez, Faustino Cardoso, 2003. Manejemen Sumber Daya Manusia. Yogyakarta: Penerbit Andi.

Gibson, James L et al, 2008, Organisasi dan Manajemen: Perilaku, Struktur, Proses, Edisi Keempat, Terjemahan, Erlangga, Jakarta

Hidayat, A.A.A 2004, Pengantar Konsep Dasar Keperawatan, Salemba Medika, Jakarta

Huber, D.L. (2006). Leadership and nursing care management. (3rd Ed). USA: Elsevier dalam Asmuji

Hasibuan, Malayu SP, 2004. Organisasi dan Motivasi Dasar Peningkatan Produktifitas, Bina Aksara, Jakarta.

Herman, AR, D, dan Ibrahim, S. (2014). Pengaruh Iklim Organisasi dan Kepuasan Kerja terhadap Kinerja Guru. Jurnal Administrasi Pendidikan (tesis). 4 (2): pp157-167

Holloway, J. B, 2012. Leadership Behavior and Organizational climate; An Empirical Study in a Non-Profit Organization, Emerging Leadership Journeys, Vol. 5 Iss.1, pp. 9-35.

Junandi, S., dan Maryono. (2012). The Influence Of Organizational Climate for Librarian's Performance In Universitas Gadjah Mada. Jurnal Manajamen edisi kedua belas.

Kreitner, R, \& Kinicki, Angelo.(2014). Perilaku Organisasi ed.9.Jakarta: Salemba Empat.

Kusnadi. (2006). Pengantar Keperawatan Profesional. Jakarta: EGC 


\section{TMM JURNAL MAGISTER MANAJEMEN UNIVERSITAS MATARAM

Kustianto, (2015), "Pengaruh Iklim Organisasi Terhadap Komitmen Karyawan Dengan Kepuasan Kerja Sebagai Variable Intervening Pada PT Garam (Persero)", Universitas Narotama, Vol I (1).

La folette W, 1975, "How is the climate your Orgnization Personal journal".

Litwin, G. H, Stringer, R.A, 1968, Motivation and Organization Climaate, Harvard University, Cambridge, MA

Lubis, Y. (2012), “Pengaruh Karakteristik Individu, Karateristik Pekerjaan , Iklim Organisasi Terhadap Kepuasan dan Kinerja Karyawan", Fakultas Pascasarjana Universitas Pasundan. Vol 11 (2).

Maharani, P.A., dan Triyoga, A. 2012. Kejenuhan Kerja (Burnout) dengan Kinerja Perawat dalam Pemberian Asuhan Keperawatan. Jurnal STIKES. Desember, vol. 5, 167178.

Mangkunegara, AP. (2005). Perilaku Organisasi. Refika Aditama, Bandung. A.P., (2009). Manajemen Sumber Daya Manusia, Bandung : Remaja Rosdakarya.

Martoyo S.( 2007) Manajemen Sumber Daya Manusia, Yogyakarta: BPFE.

Maryam, R. (2009), Pengaruh Gaya Kepemimpinan dan Budaya Organisasi Terhadap Kinerja Karyawan Melalui Kepuasan Kerja Karyawan sebagai Variabel Intervening (Tesis). Program Megister Manajemen Universitas Diponorogo.

Mathis, Robert L. dan Jackson, John H. 2006. Manajemen Sumber Daya Manusia (edisi ke10). Terjemahan Jimmy Sadeli dan Bayu Prawira Hie. Jakarta: Salemba Empat.

Murty Windy Aprilia dan Hundiwinarsih Gunasti. 2012. “ Pengaruh Kompensasi Terhadap Kinerja Karyawan Dengan Motivasi Kerja Sebagai Variabel Moderasi (Studi Pada Bank Syariah Mandiri Kantor Cabang Yogyakarta), Jurnal Ekonomi dan Bisnis Islam | Vol. IX, No. 1, Desember 2014

Nitisemito, A.S. (2004), Manajemen Personalia.Manajemen Sumber Daya Manusia, Jakarta: Penerbit Ghalia Indonesia.

Nawawi, H., (2006), Kepemimpinan Mengefektifkan Organisasi, UGM.

Nursalam (2008). Manajemen Keperawatan: Aplikasi Dalam Praktek Keperawatan Keperawatan Profesional. Edisi 2. Salemba Medika, Jakarta.

PPNI (2012), Standar Praktek Keperawatan Perawat Profesional, Jakarta.

Pramitasari, Riska Eriyani (2013). Organizational Citizenship Behavior (OCB) Pada Perawat. Jurnal ilmiah psikologi terapan. Fakultas psikologi Universitas Muhammadiyah Malang. P.430-446

Prayoga, G. (2009), Keseteraan GenderPerawat Laki-Laki dan Perawat Perempuan Dalam Pelayanan Kesehatan, Universitas Sebelas Maret.

Putra, Sudariani (2015), “The Correlation Of Organizational With Job Satisfaction Of Nurses At The General Hospital Of Mataram," Makalah Disampaikan Emphasize The Art Of Nursing On Research, Education Into Clinical And Community Practise, "The 6 th International Nursing Conference", Surabaya, 16-17 Nov.

Rivai, V., (2003), Manajemen Sumber Daya Manusia Untuk Perusahaan Dari Teori ke Praktik, Jakarta: Raja Grafindo Persada.

( (2009), Manajemen Sumber Daya Manusia Untuk Perusahaan Dari Teori ke Praktik, Jakarta: Raja Grafindo Persada. 


\section{IMM JURNAL MAGISTER MANAJEMEN UNIVERSITAS MATARAM

Robbins, Stephen P. 2003. Perilaku Organisasi : Konsep, Kontroversi, Aplikasi, Jilid I, Penerjemah: Hadyana Pujaatmaka Dan Benyamin Molan, Penerbit, Prenhalindo, Jakarta.

, (2006). Organizational Behaviour.12nd edition. New Jersey : Upper Saddle River.

Robins,\& Judge. (2015). Perilaku Organisasi ed.16.Jakarta: Salemba Empat.

Rosnaniar, (2013). Pengaruh Iklim Organisasi Terhadap Kepuasan Kerja Perawat Pelaksana Diruang Rawat Inap RSUD Ince Abdul Moeis Samarinda. (Tesis) Program Pascasarjana Universitas Hasanuddin Makassar.

Runtu, D.Y.N., dan Widyarini, M.M.N. 2009. Iklim Organisasi, Stres Kerja dan Kepuasan Kerja pada Perawat. Jurnal Psikologi. Juni, vol. 2, 107-112.

RSUD Kota Mataram.(2015). "Profil RSUD Kota Mataram."

Siagian, Sondang P. 2002. Kiat Meningkatkan Produktivitas Kerja. Cetakan Pertama. PT. Rineka Cipta. Jakarta.

Sutrisno, Edy. 2012. Manajemen Sumber Daya Manusia. Edisi 1. Cetakan Keempat. Prenada Media Group. Jakarta. Dalam Agung Dwi Waluyo Kusni ingsih, pengaruh kepemimpinan, kepuasan kerja dan motivasi kerja terhadap kinerja karyawan terminal peti kemas semarang (tpks) pelabuhan indonesia iii tanjung mas di semarang

Soepriyanto, J. (2000). Penelitian Kinerja dan Pengembangan Karyawan, Yogyakarta:Pustaka Pelajar Offest.

Stringer \& Robert.(2002).Leadership and Organizational Climate. New Jersey: Prentice Hall.

Simamora, H. (2001). Manajemen Sumber Daya Manusia, Cetaka 3, STIE YKPN, Yogyakarta

Sugiyono. 2004. Metode Penelitian Bisnis. Cetakan ke-6. Alfa Beta, Bandung

Sugiyono. (2013). Metode Penelitian Manajemen. Bandung : Alfabeta

Suyanto. (2008). Mengenal Kepemimpinan dan Manajemen Keperawatan di Rumah Sakit. Jogjakarta : Mitra Cendikia Jogjakarta

Suwatno \& Priansa, D.J. 2011.Manajemen SDM Dalam Organisasi Publik dan Bisnis, Bandung: Penerbit Alfabeta.

Suyanto. (2008). Mengenal Kepemimpinan dan Manajemen Keperawatan di Rumah Sakit. Jogjakarta: Mitra Cendikia Jogjakarta.

Umar, Husein. 2003. Metodologi Penelitian: Aplikasi dalam Pemasaran. Jakarta: Gramedia Pustaka Utama

Utami, D.R.R.B. 2005. Hubungan Iklim Organisasi dengan Kepuasan Kerja Perawat Pelaksana di Ruang Rawat Inap RS PKU Muhammadiyah Karanganyar. Jurnal Kesehatan Surya Medika.

Ulhaq, D. (2013). Pengaruh Gaya Kepemimpinan Dan Iklim Organisasi Terhadap Kinerja Karyawan Dengan Kepuasan Kerja Sebagai Variabel Intervening (Studi Pada Bank Mandiri Cabang Gresik). Tesis Magister Manajemen Universitas Muhammadiyah Malang.

Wahyuni, E.T. (2010). Pengaruh Kompensasi, Iklim Organisasional, dan Kepuasan Kerja terhadap Kinerja Karyawan PT. Madu Baru Yogyakarta. Jurnal Karisma, 4 (2): pp68-78.

Wibowo. (2010). Manajemen Kinerja : Edisi ketiga. Jakarta: Rajawali Pers. 


\section{TMM JURNAL MAGISTER MANAJEMEN UNIVERSITAS MATARAM \\ UNRAM VOL. 6 No. 1 MARET 2017}

Wijaya, Cece \& Tabrani Rusyan. 1994. Kemampuan Dalam Komuikasi. Bandung: Remaja rosda karya.

Wirawan. (2008). Budaya dan Iklim Organisasi : Teori, Aplikasi dan Penelitian. Jakarta: Salemba Empat.

Widyastuti, E.N. (2004). Analisis pengaruh Iklim Organisasi dan Motivasi Kerja terhadap Kinerja Pegawai Melalui Variabel Intervening Kepuasan Kerja (Studi Empiris pada Dinas Pertanian Kota Semarang). Tesis Magister Manajemen Universitas Diponegoro.

(2011), Peraturan pemerintah Reepublik Indonesia Nomor 46 tahun 2011 Tentang Penilaian Prestasi Kerja Pegawai Negri Sipil. 